Vol 4 No 1 Tahun 2019 (55-59)
JurnalTerapanIlmuKeolahragaan
$\mathrm{http} / / /$ ejournal.upi.edu/index.php/JTIKOR/

\title{
Analisis Permainan Bola Voli Pada Putaran Final Four Proliga Tahun 2017 Berbasis Video Recorder
}

\author{
Didin Budiman ${ }^{\bowtie}$, Agus Rusdiana \\ Program Studi Ilmu Keolahragaan, Departemen Pendidikan Kesehatan dan Rekreasi \\ Fakultas Pendidikan Olahraga dan Kesehatan, Universitas Pendidikan Indonesia \\ Jln Dr. Setiabudhi No 229, Bandung, Indonesia
}

Kata Kunci:

Analisis, Bolavoli, Proliga, Video recorder

\begin{abstract}
Penelitian ini menggunakan metode pendekatan deskriptif komparatif. Populasi yang diambil dalam penelitian ini adalah peserta kejuaraan proliga 2017. Peneliti menggunakan populasi dari tim yang lolos ke semi-final kejuaraan proliga 2017 karena didalamnya terdapat persaingan yang cukup ketat untuk merebut juara pertama dan mempertahankan gelar sebagai juara tahun lalu dan untuk mempersiapkan menghadapi kejuaraan-kejuaraan yang akan datang. Dengan sampel adalah 20, tim yang menjadi juara pada kompetisi proliga 2017. Tujuan penelitian ini adalah untuk mengetahui apakah ada perbedaan perolehan point yang didapatkan dari teknik dasar antara tim putra yang dilaksanakan di Bandung dengan di Solo dan pertandingan putri yang dilaksanakan di Bandung dengan di Solo pada kejuaraan proliga 2017. Hasil penelitian menunjukkan bahwa pada permainan bola voli putra tidak terdapat perbedaan perolehan point yang signifikan dari teknik dasar bola voli putra yang di laksanakan di Bandung dengan di Solo dan putri yang dilaksanakan di Bandung dengan di Solo. Untuk teknik dasar bola voli yang harus dikuasai dengan sebaik-baiknya pada permainan sektor putra adalah spike begitupun pada permainan sektor putri teknik yang harus dikuasai dengan sebaik-baiknya adalah spike.
\end{abstract}

\begin{abstract}
This research uses a comparative descriptive approach. The population taken in this study is the participants of the 2017 proliga championship. Researchers used the population of the teams that qualified for the 2017 semi-final of the Progressiga championship because there was quite a tight competition to win first place and defend the title as last year's champion and to prepare for the championships. which will come. With a sample of 20, the team won the 2017 proliga competition. The purpose of this study was to find out whether there were differences in points obtained from the basic techniques between men's teams conducted in Bandung with Solo and women's matches held in Bandung with Solo in the 2017 proliga championship. The results showed that in the men's volleyball game there was no significant difference in the acquisition of basic volleyball techniques for men carried out in Bandung with Solo
\end{abstract}


and girls conducted in Bandung with Solo. For the basic technique of volleyball that must be mastered as well as possible in the game of the male sector is a spike as well as in the female game sector the technique that must be mastered as well as possible is a spike

(C) 2019 UniversitasPendidikan Indonesia 


\section{PENDAHULUAN}

Bolavoli merupakan salah satu cabang olaharaga yang cukup populer di Indonesia. Hal ini terbukti bahwa hampir sebagian besar masyarakat indonesia sudah mengenal permainan bolavoli. Banyak sekali tim di Indonesia yang terbentuk mulai dari tim yang ada di sekolah yaitu tim ekstrakulikuler sampai ke klub amatir dan professional.

Sampai saat ini di Indonesia selalu mengadakan kejuaraan bolavoli yang diselenggarakan oleh Persatuan Bolavoli Seluruh Indonesia (PBVSI) yang diberi nama yaitu proliga. Proliga ini merupakan nama kejuaraan nasional bolavoli yang resmi dan sangat bergengsi yang ada di Indonesia, kojuaraan ini dilakukan setiap tahun. Proliga pertama kali dilaksanakan pada tahun 2002 tepatnya dari tanggal 1 Februari sampai 7 April 2002 dan digelar di lima kota yaitu: Jakarta, Bogor, Bandung, Yogyakarta dan Gresik dengan partai final dilaksanakan di Jakarta tepatnya di Istora Gelora Bung Karno,

Sepanjang kejuaraan proliga dari mulai tahun 2002 sampai 2016 belum ada tim yang terus menerus secara beruntun selama tiga tahun mendapatkan juara kesatu baik itu di sektor putri maupun disektor putra (Aat, 2016). Hal itu menimbulkan pemikiran bahwa di indonesia ini belum ada bagian dari pelatih yang benar-benar memperhatikan menganalisis permainan putra maupun tim putri maka dari itu perlu nya di ketahui gambaran dari permainan bolavoli sekaligus mengetahui teknik yang selalu di gunakan dalam permainan bolavoli dan paling banyak menghasilkan point, kemudian perlunya diketahui gambaran permainan putra dengan permainan putri dan untuk mengetahui lebih banyak menggunakan macam teknik mana yang selalu menghasilkan point. Pada pertandingan bola voli, (Ahmadi, 2007) mengatakan "Pukulan keras atau smash, disebut juga spike, merupakan bentuk serangan yang paling banyak dipergunakan dalam upaya memperoleh nilai oleh suatu tim" penulis akan meneliti guna untuk lebih meyakinkan.

Mengacu ke dalam permainan bolavoli bahwa dari setiap regu yang memainkan permainan bolavoli Menurut (Wiratam,A.2016). terdapat 4 peran penting yaitu "tosser (setter), spiker (smash), libero, dan Defender (pemain bertahan)". Tosser atau pengumpan adalah orang yang bertugas untuk mengumpan bola kepada teman-temannya dan mengatur jalannya permainan. Spiker bertugas untuk memukul bola agar jatuh di area pertahanan lawan. Libero adalah pemain bertahan yang bebas bisa masuk dan keluar (digantikan dengan bebas) tetapi tidak boleh memukul bola dengan meloncat melewati tinggi net. Defender adalah pemain yang memiliki tugas bertahan untuk menerima serangan dari tim lawan (Sherly Dessianti, 2015)

Meskipun sudah memiliki tugasnya masing-masing setiap pemain tetapi ketika permainan berlangsung tidak menjadi sebuah kepastian apakah tehnik yang paling banyak menghasilkan point itu dari spike (serangan utama) ataukah dari blocking (bendungan) atau bisa juga dari serangan pertama yaitu service dengan meloncat (jump service).

Berdasarkan latar belakang tersebut, maka dalam hal ini penulis bermaksud untuk melakukan penelitian ini

\section{METODE}

Dalam penelitian ini, metode penelitian yang penulis gunakan adalah penelitian Deskriptif Komparatif. Berdasarkan topik penelitian, maka populasi dari penelitian ini menggunakan video pemain bolavoli putra dan putri pada kejuaraan proliga tahun 2017 yang dilaksanakan di dua tempat. Populasi dalam penenlitian ini berjumlah 56 dari 4 tim (putra) dan 56 dari 4 tim (putri). Teknik sampling yang digunakan dalam penelitian ini yaitu random sampling dengan membandingkan dua kelompok.

Sampel penelitian ini adalah 20 orang (10 Putra) dan (10 putri). Dalam penelitian ini peneliti menggunakan instrumen observasi, (Arikunto, 2013) "dalam peroses observasi (pengamat) tinggal memberikan tanda atau tally pada kolom tempat peristiwa muncul. Itulah sebabnya maka cara bekerja seperti inilah disebut sistem tanda (sign system)".

Instrumen dalam penelitian ini menggunakan analisa secara manual dengan memanfaatkan hasil yang didapatkan dari alat ukur kamera. Setelah nilai perolehan point secara manual di diketahui, maka dilakukan analisis statistika. Data yang di analisis pada penelitian ini adalah hasil perolehan point berdasarkan ke tiga teknik dasar yang menghasilkan point pada permainan bolavoli. 
Analisis selanjutnya yaitu menentukan perbedaan signifikansi untuk masing-masing data. Perbandingan dilakukan terhadap satu data dengan data yang lainnya. Uji statistik yang digunakan untuk analisis ini adalah uji normalitas, uji homogenitas, Independent simpel t tes dan Mann-Whitney.

\section{HASIL DAN PEMBAHASAN}

Berdasarkan hasil uji hipotesis dengan teknik Mann Whitney maka dapat diketahui bahwa nilai perolehan point dari keterampilan Service pada Tabel 4.7 diperoleh nilai z sebesar 0,313 dan nilai probabilitas (p) adalah 0,754 ( $p>$ 0,05). Hal ini menunjukkan bahwa Ho diterima, atau tidak terdapat perbedaan teknik yang paling banyak menghasilkan point pada pertandingan bolavoli tim putra dilaksanakan di Kota Solo dengan di Kota Bandung dan tim putri yang dilaksanakan di Kota Solo dengan di Kota Bandung pada putaran final four proliga tahun 2017.

b. Uji Hipotesis Perolehan Point dari Keterampilan Block

Berdasarkan hasil uji hipotesis dengan teknik Mann Whitney maka dapat diketahui bahwa nilai perolehan point dari keterampilan Block pada Tabel 4.4 diperoleh nilai $\mathrm{z}$ ialah sebesar -0,038 dan nilai probabilitas (p) sebesar $0,970$ ( $p>0,05)$ (Hal ini menunjukkan $p>0,05$ maka Ho diterima, atau tidak terdapat perbedaan teknik yang paling banyak menghasilkan point pada pertandingan bolavoli tim putra dilaksanakan di Kota Solo dengan di Kota Bandung dan tim putri yang dilaksanakan di Kota Solo dengan di Kota Bandung pada putaran final four proliga tahun 2017.

c. Uji Hipotesis Perolehan Point dari Keterampilan Spike

Berdasarkan hasil uji hipotesis dengan teknik Mann Whitney maka dapat diketahui bahwa nilai perolehan point dari Keterampilan Spike pada Tabel 4.4 diperoleh nilai $\mathrm{z}$ ialah sebesar 0,344 dan nilai probabilitas (p) sebesar , 0,731 $(\mathrm{p}>0,05)(\mathrm{Hal}$ ini menunjukkan $\mathrm{p}>0,05$ maka Ho diterima, atau tidak terdapat perbedaan teknik yang paling banyak menghasilkan point pada pertandingan bolavoli tim putra dilaksanakan di Kota Solo dengan di kota Bandung dan tim putri yang dilaksanakan di kota Solo dengan di Kota Bandung pada putaran final four proliga tahun 2017.

Berdasarkan pada analisis hasil analisis statistika, peneliti tidak menemukan perbedaan perolehan point yang signifikan dari ke tiga teknik dasar bolavoli yang dilaksanakan di Bandung dengan di Solo teknik yang paling banyak menghasilkan point dari pertandingan putra di Bandung dengan Solo dan pertandingan putri yang dilaksanakan di Bandung dengan Solo keduanya adalah sama dari teknik spike kemudian service adalah urutan yang kedua yang paling banyak menghasilkan point dan urutan yang ketiga adalah teknik block dari ketiga teknik tersebut tidak ada perbedaan yang signifikan dalam perolehan point antara pertandingan tim putra yang dilaksanakan di Bandung dengan di Solo dan tim putri yang dilaksanakan di Bandung dengan di Solo pada putaran final four kejuaraan proliga tahun 2017

\section{KESIMPULAN}

Keterampilan bolavoli yang banyak menghasilkan point pada pertandingan putra yang dilaksanakan di Kota Solo dengan di Kota Bandung pada putaran final four proliga 2017 adalah keterampilan spike. Karena pada pertandingan putra, dibutuhkan teknik yang dapat menjatuhkan bola dengan keras dan cepat. Keterampilan bolavoli yang banyak menghasilkan point pada pertandingan putri yang dilaksanakan di Kota Solo dengan di Kota Bandung pada putaran final four proliga 2017 adalah spike. Karena pada pertandingan putri sama seperti pertandingan putra, dibutuhkan teknik yang dapat menjatuhkan bola dengan keras dan cepat ke arah yang kosong. Dan tidak terdapat perbedaan yang signifikan dari ketiga teknik yang dilaksanakan pada pertandingan putra di Kota Solo dengan di Kota Bandung begitupun dengan tim putri tidak terdapat perbedaan yang signifikan perolehan point yang di laksanakan di Kota Solo dan di Kota Bandung. Keterampilan yang spesifik harus dikuasai dan di antisipasi dengan sunguhsunguh oleh atlet bolavoli proliga 2017 adalah spike. Karena pada pertandingan putra, diperlukan teknik yang dapat menjatuhkan bola dengan keras dan cepat ke arah yang kosong. Teknik spike lah yang memenuhi kriteria seperti itu. Begitupun dengan pertandingan di sektor putri. 
Hasil penelitian ini, maka implikasi dan rekomendasi yang dapat dikemukakan adalah ketiga keterampilan bolavoli bisa menghasilkan point, maka dalam hal ini harus diberikan latihan yang intensif khususnya pada teknik dasar spike (pukulan) kepada para pemain bolavoli untuk meningkatkan prestasi. Karena dengan meningkatnya kemampuan seluruh $c l u b$ yang ada di Indonesia, maka persaingan semakin ketat, yang sekaligus memotivasi seluruh club dari berbagai kota yang ada di Indonesia untuk terus meningkatkan kemampuan teknik spike juga harus berlatih dengan sungguh-sungguh untuk mengantisipasinya teknik spike dari lawan. Sehingga nanti tim terbaik dalam teknik spike dan tim yang baik cara mengantisipasi teknik spike akan menang dan terpilih menjadi juara di tingkat nasional maupun internasional.

\section{DAFTAR PUSTAKA}

Ahmadi, Nuril. (2007). Panduan Olahraga Bola Voli. Surakarta: Era Pustaka

Utama.

Aat. (2016) Daftar Juara Proliga. Yogyakarta: PBVSI.

Arikunto, S. (2006). Prosedur Penelitian. Jakarta: PT. Rineka Cipta.

Dessianti Sherly (2015) Posisi pemain dan tugasnya. Jakarta: PBVSI

Riyanto, Viter. (2011). Analisis teknik Permainan Bola Voli Putra Pada Putaran Ke-2 Di Solo Jawa Tengah tahun 2011. (Skripsi). Fakultas Keguruan Dan Ilmu Pendidikan. Surakarta: Universitas Sebelas Maret.

Subroto dan Yudiana. (2010). Permainan Bola Voli. Bandung: FPOK Universitas Pendidikan Indonesia.

Sugiyono. (2011). Metode Penelitian Kuantitatif, Kualitatif dan R\&D. Bandung: Alfabeta

Suherman, A. \& Rahayu, N.I. (2014). Modul statistika untuk ilmu keolahragaan. Bandung: Universitas Pendidikan Indonesia.

Wiratam, A. (2016). Pemain voli harus tau 4 teknik dasar permainan bola voli. [Online].

Tersedia: permainan-bola-voli. Diakses dekatama.com/teknik-dasar- 